УДК 821.163.41.09 Попа Васко

https://doi.org/10.18485/godisnjak.2019.14.13

Урош М. Ристановић*

Универзитет у Београду

Филолошки факултет, докторанд
Оригинални научни рад

Примљен: 15. 09. 2019.

Прихваћен: 11. 10. 2019.

\title{
СТРУКТУРА ПЕСНИЧКЕ КЬИГЕ СПОРЕДНО НЕБО ВАСКА ПОПЕ
}

У раду се кроз призму структурализма разматра трећа књига из песничког опуса Васка Попе - Споредно небо, са посебним освртом на космогонијске елементе који се у њој могу препознати. Први део рада посвећен је формалним и композиционим одликама збирке, те аналогијама које се између структуре ове књиге и могуће организације космоса уочавају. Потом, анализирају се космички мотиви, њихово присуство и њихова функција у оквиру појединачних песама, циклуса, али и на нивоу целокупне збирке. Закључни део рада даје претпоставке о положају ове збирке у контексту космичке традиције српског песништва.

Кључне речи: Васко Попа, Споредно небо, структурализам, космос, космогонија, космизам, звездознанац.

Збирка Споредно небо ${ }^{l}$ Васка Попе објављена је 1968. године, и трећа је збирка песама у библиографији овог песника. Пре ње, Попа је објавио збирке Кора (1953) и Непочин-поље (1956), које су овог аутора представиле на књижевној сцени и које ће донекле трајно обележити суд о његовој поетици као нечему што је блиско народној традицији, једноставним облицима и концизности и загонетности израза својственој нашим фолклорним облицима (загонеткама, пословицама, питалицама итд).

*uristanovic@gmail.com

${ }^{1}$ Сви цитати из збирке Споредно небо наведени су према издању Попа 1973: В. Попа, Споредно небо, Београд: Вук Караџић, са наведеним бројем странице у загради након цитата. 
Споредно небо сачињено је од седам ${ }^{2}$ циклуса (Зев над зевовима, Знамења, Размирииа, Подражавање суниа, Раскол, Липа насред сриа, Небески прстен) који функционишу као целине, творећи јединствену и симболичну структуру чије интерпретације могу бити многобројне 3 Даље, сваки од циклуса саткан је од тачно седам песама, чиме се показује педантна и промишљена композиција ${ }^{4}$ књиге у којој се води рачуна како о микро, тако и о макроструктурама; због тога, чини нам се да се ова књига, њена структура и значење појединачних њених делова, морају разматрати скупа, водећи се Лотмановом мишљу да „изван структуре је уметничка идеја незамислива" (Лотман 1970: 105). Споредно небо саткано је, дакле, од укупно 49 песама које се нижу и творе јединствену песничку слику свемира. Та слика је циклична; опонашајући кретања у познатом делу космоса и постављајући и продубљујући тако ритмичну оркестрацију збирке и пре него што се дође до следећег нивоа њене садржине, песник на плану организације сопствене визије неба прави својеврстан прелудијум који носи нешто од митског призвука и, у еху, музику сфера. ${ }^{5}$

Посебно значење ове књиге може се уочити на паратекстуалном нивоу, у њеним насловима, који творе аутентичне нивое значења и путоказе за читање. Тако се самим насловом збирке Споредно небо, већ на првом нивоу сугерише да је у фокусу песничког интересовања нешто што

${ }^{2}$ „Може се опазити нумеричка пропорционалност у структури Споредног неба: нумеричка структура целине понавља се у сваком посебном делу” (Петров 1983: 205).

${ }^{3}$ Симболика броја седам је готово несагледива; у Речнику симбола Жана Шевалијеа и Алена Гербрана издвојено је тринаест његових значења, а претежно за многа његова значења је то „да је седам број кружне довршености и њене обнове” (Шевалије, Гербран 2013: 816). Нека од значења која могу бити интересантна за тумачења Споредног неба су и та да број седам симболизује „седам дана у недељи, седам планета, седам степена усавршавања, седам сфера или небеских прстена [...] седам грана космичког или жртвеног стабла у шаманизму" (Шевалије, Гербран 2013: 816); видети више у Ж. Шевалије, А. Гербран, Речник симбола (митови, снови, обичаји, поступчи, облици, ликови, боје, бројеви), Нови Сад: Stylos art, Kiša, 816-822.

${ }^{4}$ Према нашем мишљењу, овај елемент Попине поетике најбоље дефинише Борислав Радовић: „Васко је на четири жива језика хватао конце европске песничке традиције. Он је довољно рано научио да своје трагање за формом темељи на провераваном искуству, насупрот сваком поклоништву. И више од тога, брзо је увидео да се питање форме, пре него би се свело на ствар укуса или избора, дакле у извесне књижевно-историјске или естетичке оквире, намеће као питање граница слободе коју песник ставља себи у задатак да оствари.” (Радовић 2017: 12); више детаља о структури и њеном значењу у Попиној поезији видети у Шеатовић Димитијевић 2012: С. Шеатовић Димитријевић, Део као иелина \& иелина као део, Београд: Институт за књижевност и уметност.

${ }^{5}$ Поред митске и космогонијске, критика је препознала и анализирала и загонетни слој алхемијске симболике у Споредном небу. Видети више у Радуловић 2011: Н. Радуловић, Алхемија у поезији Васка Попе, у: Научни састанак слависта у Вукове дане 40/2, Београд: Међународни славистички центар, 531-539. 
не припада централној линији имагинације и искуства, ствар по нечему особена, вероватно занемарена и непримећена. Двојако је значење насловне синтагме; с једне стране, она може казивати вредносно-просторну позицију одређеног неба у целини (бесконачности) васионе, а с друге, може говорити и о жељи песника да на иновативан начин опише настанак космоса (будући да би појам небо могао да се односи не само на једну галаксију, већ и на појам универзума).

Потом, на средишњем паратекстуалном нивоу, насловима циклуса (Размирице, Раскол) читаоцу се предочава својеврсна космичка драма, чији се пут кроз ову збирку има прећи. Називи појединих циклуса носе и нешто од метапоетског карактера (Небески прстен), повезујући и обзнањујући поступак уланчавања и прстенасте структуре који је у основи ове Попине збирке, али и његове поетике. Јасно, и на трећем нивоу надтекстовних елемената приметна је особина репетитивности и међусобног повезивања, која се може утврдити на равни истоветних мотива у насловима песама: истог циклуса (Подражавање сунца - Слепо суние, Поноћно сунце, Страно суние, Подражавање суниа), различитих циклуса (Знамења - Осуђен бодеж; Липа насред срия - Кроћење бодежа), иницијалних позиција уводног и финалног циклуса (Зев над зевовима - Звездознанчева оставштина; Небески прстен - Звездознанчева смрт) итд.

Паратекстуална значења не функционишу само на хоризонталном нивоу, већ се њихова семантика усложњава на вертикалном плану. Тако, на пример, можемо приметити како сваки циклус значењем конгруира и функционише као ћелија организма ${ }^{6}$ Споредног неба, како истовремено бива елемент његовог описа, али и део његове садржине. Исто се дешава и са појединачним песмама, које се додатно формално и значењски ушивају за циклусне целине, понављајући каткад њихов назив и представљајући одјек надидеје и мисли и на микроплану. Тако је именовање последњег циклуса истоветно другој песми која се у њему налази (Небески прстен), а чак у три циклуса њихови називи се јављају и као називи последње њихове песме (Зев над зевовима, Подражавање суниа, Липа насред сриа).

\footnotetext{
${ }^{6}$ Овде појам органски користимо наспрам појма механицистички. Верујемо у то да се у традицији певања о космосу у нашој поезији успостављају две линије; прва, она која космос види као својеврсни механизам, који је математички уређен, у коме се промена јавља као квар због кога један његов део престаје да ради, који функционише као машина, строј; друга, она која космос види као организам који се понаша као живо биће, поседује фазе у егзистенцији (од рађања до смрти) и склон је променама. Основни елементи: организам - ћелије, механизам - зупчаници. Организам има свест, има самосвојност, може бити стваран и разаран, те адаптибилан. Механизам ради по такту, нема слободу кретања, може бити створен и коригован, али није адаптибилан нити регенеративан.
} 
Оваквим поступним, детаљистичким и до у танчине промишљеним ткањем Споредног неба, коме није одузето ништа од природности тока и карактера живог бића, ова творевина и визија одише духом органског космоса, чији елементи, условљени значењем и песничким моделовањем, постоје на прецизним местима, бивајући истовремено тежишне тачке како форме, тако и семантичког плана књиге.

Збирку отвара циклус Зев над зевовима, који чине песме Звездознанчева оставштина, Забораван број, Охола грешка, Мудар троугао, Скамењени одјеци, Прича о једној причи и песма Зев над зевовима. Цикличност ове песничке седмине обезбеђена је завршном песмом циклуса, по којој је целина названа, а која условно доноси saldo искуства опеваног у претходним песмама. Доминанта која се може уочити на нивоу овог циклуса препознаје се у уводним стиховима шест од седам песама; образовани путем познате иницијалне формуле карактеристичне за бајку (,Био једном један број” (14), „Била једној једна грешка” (15), „Био једном један троугао” (16), „Било једном безброј одјека” (17), „Била једном једна прича” (18), „Био једном један зев” (19)), ови стихови представљају почетак нарације о космосу ${ }^{7}$. Будући да своје песме каткад формира као загонетке „што им је одгонетку метнуо у наслов” (Петковић 2004: 223), код Попе не треба да нас зачуде одређене инверзије, те пут наслућивања значења треба отпочети на неконвенционалан начин, од самог краја.

Имајући у виду да се иницијална формула својствена бајци јавља у свим песмама осим у првој, у извесном смислу њу можемо сматрати и последњом у циклусу; томе сведочи и њен почетак: „Остале су за њим юегове речи" (13), који се разликује од осталих почетака песама из овог

\footnotetext{
${ }^{7}$ Попина свест о традицији песме о космосу види се и у антологији Поноћно сунце: зборник песничких сновиђењ $а$ из 1962, у којој он даје легитимитет таквој врсти инспирације, али и испитује традицију песништва, тражећи аутентичан пут за своје поетско истраживање свемира: „Да би уопште могао унети нешто ново у поезију, он није смео потпуно одбацити наслеђе, изгубити дослух са традицијом. Али, да би успоставио сопствени однос према наслеђу, испрео своју нит традиције, у много чему је морао лака срца раскинути са претходницима, а и савременицима. [...] Из тог угла, свако туђе искуство, и када би му бивало драгоцено, постајало би то пре свега негативно искуство [...] Споредно небо је, уз Непочин-поље, за њега морало значити највећи изазов. Та џепна космогонија захтевала је све његово познавање одговарајућих особености из културног и књижевног наслеђа, све мајсторство одабирања и комбиновања, сву његову уобразиљу” (Радовић 2017: 14-18). Напослетку, имајући у виду Попино бављење овом тематиком, не бисмо погрешили ако бисмо рекли да је Поноћно сунцее припрема за грађење сопственог сновиђења, чему сведочи и датирање са краја збирке Cnoредно небо (1962-1968).
} 
циклуса ${ }^{8}$ и која као да, слично финалној формули бајке, доноси прави закључак мисли изражене у циклусу и тражени епилог.

Звездознанчева оставщтина је кључ за читање Споредног неба. Она показује да је интересовање ове песничке збирке (материјал од ког је она саткана) кондензовано у синтагми звездознанчевих речи - његове оставштине. Дакле, у уводној песми збирке дат је извор песничке имагинације, управљен ка космичкој визији утемељеној на знању (речима) астронома, док се метафизичка компонента представља као нијанса амбијента саме песме/збирке. Опис тих суштаствених речи дат је у форми низа поређења извршених путем речи него, где се значење познатих појмова употребљава као референтна тачка од које звездознанчева оставштина по квалитету одступа, које надвисује и немерљиво прераста; оне су тако: „Лепше него свет [...] Веће него људи [...] Теже него кости живота" (13). Њихова карактеризација извршена је и ефектном употребом глагола којима се речи антропоморфизују 9 : „Остале су за юим юегове речи [...] Чекају на окукама времена [...] Леже на мутавој земљи" (13), а којима се исказује да речи не могу бити изговорене, али да оне одређују судбину или су у њу уписане, да превазилазе смрт и значе вечност. У осталим стиховима се сугерише и то да су речи претешке и необориве, али и да у њима има нешто од мита проклете лепоте: „Лепше него свет / Нико не сме у њих да се загледа" (13).

Зашто су те речи такве? Зато што је у њима есенција истине које звездознанац, гледајући у васиону, открива. У његовим речима крију се истовремено истина о стварању космоса, о његовом поретку и начину организације и функционисања; такође, он је тај који бележи хронику космоса, који може да мења, прећути или каже историју: „Звезде падалице главе склањају / У сенке његових речи" (13).

Идући даље кроз циклус, откривају се елементи Звездознанчеве оставитине, његових речи, које у првом циклусу служе да опишу својеврсну космогонијску ситуацију и услове стварања Споредног неба. У основи Попине космогоније срећу се Забораван број, Охола грешка, Мудар троугао, Скамењени одјеци, Прича о једној причи и Зев над зевовима - бајковите песме које говоре о томе како је настао универзум. Ту се даје претпоставка

\footnotetext{
${ }^{8}$ Није на одмет поменути да се ова песма и графички разликује од других, будући да је штампана курзивом. Ово није усамљен пример у Попиним песничким књигама, али су, према мишљењу аутора овог текста, истакнуте песме у Споредном небу у дубљем дослуху; осим песме Звездознанчева оставштина, косим слогом штампана је и песма Звездознанчева смрт, из последњег циклуса.

${ }^{9}$ О персонализацији антропоморфне песничке имагинације видети више Петров 1983: А. Петров, Крила и ваздух, Београд: Народна књига, 205-232.
} 
о томе како, из досаде и смелости једног броја (14), као производ основних рачунских операција (сабирања, одузимања, множења, дељења), настају звезде, сунце и други космички објекти. А корен универзума дат је не у помпезности каквих представа о празнини и експлозијама нагомиланих енергија, већ кроз једну кратку напомену да је на почетку: „Био једном један број / Чист и округао као сунце / Али сам много сам". Дакле, да из самоће, игре и доколице настаје свемир, и да је основа ове песничке космогоније покушај да се једна несрећна околност (усамљеност) укине. На ту самоћу се надовезују: охолост једне грешке (15) која је заслужна за стварање простора, времена и људи - хронотопа и сведока - које је измислила да би показала да не постоји; затим мудрост троугла (16) и скамењеност одјека (17) који сведоче дубину димензија и кретања по космосу, али и самосвојност његових конститутивних елемената; напослетку, ту су и сами занатски коментари у Причи о једној причи и Зеву над зевовима, који разотркивају парадоксалност нарације и показују да се само у причи и мисли могу стварати и доконавати читави светови.

Сва материја првог циклуса уланчана је и органски повезана са појмом звездознанчеве оставштине, датим на почетку, са његовим речима, те чини садржину и поруку коју непознати астроном оставља а коју песник лирски обликује и обрађује.

Други циклус, назван Знамеља, не одступа од насловног одређења. У њему су каталошки побројани и обрађени појмови који означавају, наслућују, антиципирају и доказују суптилна померања на космичкој позорници. Доминанта овог циклуса може се препознати у донекле песимистичнијем тону, који насупрот космогонији и стварању из прве седмине, овде одзвања и оглашава аномалије и свемирске нуспојаве, због којих се свака појединачна песма може читати и у алегоријском кључу. Такође, у чак четири песме последњи стихови експлицитно постављају питање смисла тих злослутних знамења, њиховог присуства и улоге у слици универзума.

У првој песми циклуса уведен је појам Уљез, који се јавља с пацифистичком мишљу и сугерише сувишност коју „Кап крви у углу неба” (23) значи. Осим што квари савршену представу, у двострукости значења се та крв указује, парадоксално, и као неопходна, јер се управо посредством ње открива да у космосу постоје и поједини ћорави углови, и да су неке појаве и догађаји занемарени и заташкани: „За сунчевим округлим столом / Не говори се ништа о томе" (23). Ова песма, могуће, представља и својеврсну критику друштва и система, окретања главе од реалних проблема и историјских трагедија, те тежњу цивилизације за материјалним и телесним. 
На сличан начин песма Крилата свирала може бити схваћена као алегорична, у којој се појава насловног предмета ставља у контекст муња које ће је сагорети пре него успе да их намами: „Да ли натраг у облаке / Или на друго лепше небо / Или на земљу међу људе" (24). Њено кретање кроз универзум симболично се повезује са кретањем свих знамења, чиме се указује на систематичност и садејство различитих елемената у једном организму.

Једнак елемент крви и свирали чине и Тврдоглави завежљај, Глава бескућница, Осућен бодеж, Запаљене руке и Последње уже. У свакој од тих песама фигурира по један сигнум небеске позорнице, који, сваки на свој начин, указује на поједине карактеристике космоса (на кретање, равнотежу, поредак, регенерацију и бесконачност). Описујући у циклусу Знамења само специфичне и симболичне елементе космичког платна, песник већ у другој седмини уводи дисонантне и дисперзивне тонове у своју визију, те од њих Споредно небо губи потенцијал утопијског, а добија могућност и аргумент свеобухватног и органског концепта космоса, али и комичног и хумористичног призвука ${ }^{10}$.

Већ смо рекли да поједини циклуси уводе на лирску позорницу својеврсну драму ${ }^{11}$, какав је случај са седмином названом Размирица. Образована начелно у дијалошкој форми (питања у непарним, одговори у парним строфама), ова целина доноси седам песама у којима се наслућује и нуди решење и за поједине претходне песме (Забораван број), али и путоказ за читање другог дела збирке. Ипак, појачана динамика која се добија како елементом драме који је уткан у циклус тако и дијалошком основицом, ублажена је складним ритмом песама који произилази из чињенице да је метар овог циклуса доведен готово до перфекције; већина песама испевана је у осмерцу (који претеже у збирци), са изузетком деветерца у песми Плава омча.

${ }^{10}$ „То је права мала демонологија, најпотпунији приручник Васкових црнохуморних и иронијских спрегова и обрта. Завођење и отрежњење руку под руку ту воде коло и смењују се у контрапункту који даје јединствено бйло свакој појединој песми и целини" (Радовић 2017: 19); такође, овим аспектом Споредног неба се бави Александар Петров у тексту Апсурдна комедија (Петров 1983: 205-232).

${ }^{11}$ Александар Петров у овоме види и уплив конкретних драмских чинилаца, попут људског хора: „Људски хор је други јунак Споредног неба. Хор се појављује у поглављима у којима постоји драмски дијалог и у поглављима која се казују у првом лицу множине. (Та су поглавља симетрично распоређена: драмски дијалог - хор - драмски дијалог - хор) (Петров 1983: 205-206). 
Разговор ${ }^{12}$ у Крунисаној јабуц̧и, првој песми циклуса, који је понегде у литератури означен и као „космогонијска борба између светлости и мрака” (Попин 2015: 146), образован је у два гласа: први, колективни, изражен кроз прво лице множине, оглашен је у дистисима у првој и трећој строфи; други, индивидуални, изражен кроз прво лице једнине, јавља се у другој и четвртој строфи у терцинама. Колективни глас експлицира незадовољство, императивом упућујући захтеве непознатој инстанци. Испуњење тих захтева је од егзистенцијалног значаја за молбенике: „Извади сунце из уста / Ноћ нас живе сахрањује" (33). Друга строфа казује нешто више о поимању индивидуалне инстанце, која је заслужна за ,прождирање сунца' у коме види своју јабуку: „Јабука је ово моја / С неба ми на језик пала / Пустите ме да је сладим" (33). Одговарајући на то образложење, колективни глас изједначава индивидуални са нулом; осим што такво именовање доноси одређен квалитативни суд, не можемо пренебрегнути чињеницу да је у питању ипак број, можда онај Забораван број из првог циклуса, који порађа космичке елементе и сам се закључава у „сунчану чистоту” (14). Последња строфа открива да је реч о баш таквом броју, усамљеном, далеком изнад других, помало себичном и охолом, који молбенике назива црвима и који сматра да им сунце ипак није потребно. Семантику таквог броја, његове појавности и улоге у дијалогу наслућује Петковић: „Јер док смо ,ми' људи, ,он' то није. И ми га не можемо сагледати: ми смо у њему и кад смо изван њега, а нисмо он мада смо у њему. ,Он' може бити и ништа, оно што нас поништава; ,нула', како је у двема песмама назван” (Петковић 2004: 226). Да је реч о броју познатом из првог циклуса, сведочи и песма Плодан жар. Њени стихови: „Зар сте толико порасли / Играјући на мом жару" (38) конгруирају са звездознанчевим описом Заборавног броја и његовог ефекта на космос: „Напољу су остали усијани / Трагови његовог рачунања" (14).

Дијалог две инстанце се кроз циклус непрестано обнавља, а кроз њега се непосредно даје метафорична слика саодноса целине и појединачних делова; док колективни глас у поменутим и преосталим песмама (Плава омча, Висок пут, Вредни конци, Подметнуто легло, Слободан лет) моли и запиткује своју целост о судбини и даљим корацима, она им попут родитеља брижљиво одговара, упућујући их ка будућности и ослобођењу. Тако ће последња песма циклуса (Слободан лет) заиста и посведочити о завршетку Размирище, у којој се иницијално именовање колектива као

${ }^{12}$ Петковић у овоме види „дијалог чији бисмо праобразац лако могли да пронађемо у митској подлози" (Петковић 2004: 227). 
„црва” трансформише, где заједница бива поређена са „птицом” уз савет: „Одрежите себи крила / Слободан да вам буде лет” (39).

Последњи савет закључује причу о било каквом неспоразуму, те и одељак у коме је звездознанчева оставштина показана непосредно, документарно, фактографски, дијалошки и драмски, остављајући простора за многобројна тумачења тек са једном извесношћу: да сунце, по одлуци броја који је ,централни кривац' стварања споредног неба, остаје заробљено и недостижно свим другим космичким елементима који то небо творе.

Судбина тог заробљавања тематизује се делом и у следећој седмини названој Подражавање сунца. У њој, израз је враћен на фон звездознанчеве оставштине, и нема ни трага од дијалогичности која је доминирала претходним циклусом. Овај одељак је обојен трагиком, и може се видети као потрага за истином о звездама и пореклу.

На његовом прочељу стоји песма Смрт сунчевог оца, која уводи појмове старог сунца које је утихнуло и умрло, те сунца које има „сина сунчевића" (43) који би требао да га наследи. Ипак, повезујући значење ове песме са низом оних које претходе, можемо закључити да је судбина старог сунца, али и његовог сина, овде пре везана за одлуку Заборавног броја, односно за оно што лежи у центру песничке визије свемира. По свему судећи, у питању је оно својство које има способности да прождире сунца, да се повлачи у себе, које је контрастирано сунцу и што симболизује помрчину, таму и смрт. Ипак, то није израз крајњег песничког космичког песимизма, јер постоји мисао да док се син сунчев: „и за нас не роди / Научићемо мрак овај да сија" (43).

Управо се на тај начин још једном потврђује да космос у овој концепцији није механицистички устројен, већ да више постоји као организам који се може прилагођавати и адаптирати, који може одговорити на нове околности и услове.

Песме Слепо сунце и Сукоб у зениту говоре о истом мотиву, о сусрету ноћи и дана кроз метафоричне приказе небеских прилика, и носе собом нешто од фолклорне заоставштине, уланчавајући се у низ са другим творевинама које Миодраг Павловић разуме под појмом српске песме која траје од памтивека. Иако се у песмама Поноћно суние и Страно суние јављају назнаке рађања новог сунца, хладноће и песимизма при космичком лутању и потрази, последњу реч у овом циклусу даје његовим насловом издвојена песма (Подражавање сунща). У њој је на симптоматичан начин приказано дивљење сунцу и емотивна опредељеност за светлосни и соларни принцип; приказом отцепљења срца од тела које, желећи да буде сјајно попут свог светлећег узора, одлази да се никад не врати, те тога 
да: „Од тада свако од нас носи / На тешком ланцу своје срце / Везано за једно верно ребро" (49), легитимише се и мотивише порекло и судбинска повезаност сваког елемента споредног неба са својим центром.

Раскол, идући циклус, други је по реду који представља драму споредног неба; за разлику од првог (Размирица), ова седмина насловом не обећава било какво разрешење антиципиране напетости, што се читањем појединачних песама испоставља као тачна претпоставка. Формално, Раскол и Размирица су у снажној комуникацији. И у овом циклусу имамо посла са тенденцијом осмерца у стиху (с изузетком појединих деветераца); за разлику од песама из Размириие, строфе у Расколу су усаглашене, будући да се песник определио за дистих као елемент од којег ће изградити песме. Такође, треба напоменути да је дијалошка структура доследно спроведена кроз одељак, те се тако два циклуса повезују на неколико нивоа и заиста се могу сматрати сродним; у томе треба приметити и оно својство ритма које Лотман дефинише: „Ритам је у стиху дистинктивно-семантички елеменат $[. .$.$] стиховна структура не само што обелодањује нове преливе$ у семантици речи - она открива дијалектику појмова за чије означавање обичан језик нема специјалних средстава" (Лотман 1970: 109).

Значење појединачних песама (Јешан дим, Колач од пепела, Угашен точак, Несагорљив калем, Грудва мрака, Огњени сунцокрет, Ужарен пољубаи) овог циклуса могло би се слутити, но смо мишљења да оне овде зраче више илустративно и да треба да, пре него нова значења и померања у грађењу космичких предела и визија, унесу нешто од емотивности, звучања и динамике у Споредно небо. Општи тон и постојање два гласа у свим песмама, те истоветна схема (питање у непарним и одговор у парним строфама) чини да ова целина звучи једном мелодијом и ритмом. Овога пута, индивидуални глас поставља питања, а колектив је тај који одговара. Из разговора (испитивања) може се прочитати смирај и нестанак више инстанце те њен последњи повратак, са којим реципрочно следи и крај колективног: „Шта радите без моје плаве славе / У својој мекој кули склоној паду / / Палимо свој последњи дах / Изнад уста твог доњег котла" (59). Оно што држи на окупу све тонове и мотиве (неки од њих, попут бодежа, понављају се у оба дијалошка циклуса), јесте простор „котлова”, који су (према решењу Душана Ристића) искоришћени и као знамење ове песничке књиге.

Садржај разговора, напослетку, утемељен је на чињеницама, догађајима и искуствима чије је порекло у диму и међупростору два котла („Напустио си ти нас на дну / Свог испражњеног доњег котла / / Тражи ти сад нас на ивици / Свог преврнутог горњег котла” (53)); аналогно, мо- 
жемо претпоставити и да се читаво споредно небо простире у тој магли и испарењима о којој два доминантна гласа из звездознанчеве оставштине проговарају. А у таквој слици, ако се она иоле приближава песниковој намери, треба видети својеврсну космогонију, кување и крчкање једног поетског неба, његово дестиловање као настанак дела свемира или макар једне његове галаксије.

На исти начин како песме непосредно након Звездознанчеве оставштине означавају заснивање комогоније, њене основне елементе и прапочетке, тако и песме пре Звездознанчеве смрти из последњег циклуса (Небески прстен) означавају њен крај, звуче апокалиптично, злослутно и есхатолошки. У том циклусу сабрана су сва искуства збирке, и дата су потенцијална решења или трагови којима би се, у трагању за значењем, могло ићи. Пажљивом читаоцу тако неће промаћи да је мотив липе већ поменут и пре овог циклуса, у песми Смрт сунчевог оца: „На три корака од врха неба / Од липе у вечном цвету / Старо је сунце застало” (43). Понављање тог мотива није нимало случајно; осим што антиципира и повезује различите елементе збирке, оно и „ствара велики семантички капацитет, уз наглашену једноставност средстава" (Лотман 1970: 125). Позиционирање старог сунца овде може да разреши питање положаја споредног неба, будући да се у претпоследњем циклусу ове збирке каже да је Липа насред сриа; аналошки, могло би се закључити или да је представљено споредно небо односно визија алтернативног космоса била опширна лирска стилизација песничког сопства (чему у прилог иде песма Риба удуши), или да је космос организам који, између осталих неопходних органа, поседује и срце као центар.

Липа, као аутентична метафора плодности, увек је цветна и способна је чак и да изнедри сунца: „Сунце ће каже сазрети / На врху липе насред срца" (63), а овде се јавља и као особен космички елемент у целокупном систему споредног неба. Нажалост, уместо да донесе нешто од светлости и снаге коју најављује, липа ће ипак послужити као својеврстна подлога да прикаже то како органска целина увек зависи и од појединачних елемената које је чине; у том смислу, сама липа нема довољну снагу (иако је њена младост и способност рађања неисцрпна) да пуким постојањем испуни улогу за коју је одређена. У низу парадоксалних и симболичних визија, кроз овај циклус сведочићемо немарности колектива (Риба у души, Страдање златног троношиа, Липа насред сриа) и ефектима његовог делања.

Напослетку, та немарност ће, и поред тога што липу цене као какво божанство („Поклонили смо се дубоко / Липи насред срца” (65); ,Заиграли 
смо сунчево коло / Око липе насред срца" (67)), ипак довести колектив до тога да јој управо они буду крвници: „Посекли смо липу да се огрејемо / Хладно нам било око срца" (69). С нестанком липе, нестаје и могућност за регенерацију и рађање новог сунца, те започиње последња етапа постојања споредног неба и свега онога што га чини.

Последњи циклус Споредног неба отвара песма Звездознанчева смрт, која се може повезати са песмом Звездознанчева оставштина, која има иницијалну позицију у збирци. Обе песме су штампане курзивом (једине у књизи); њихов метар се разликује, као и распоред стихова унутар строфа, због чега не можемо тврдити да су песме у дубљем формалном саодносу. Ипак, метар читаве последње седмине истоветан је другим циклусима (изузев Размирице и Раскола), у којем доминирају осмерци и деветерци. Такође, треба напоменути да је песма чији је наслов узет за именовање целог циклуса овога пута заузела другу позицију, чиме се сугерише њена важност.

Звездознанчева смрт тематизује, као и њена песма-посестрима, тренутак који повезује време са обе стране границе егзистенције. За разлику од прве, која афирмише значај астрономових речи, на којима је утемељена и мотивисана читава песничка збирка Споредно небо, Звездознанчева смрт доноси накратко другачији звук, који је обојен нијансом сумње. Наиме, у њој се експлицира због чега је астроном умро: „Морао је кажу да умре / Звезде су му биле ближе / Него сами људи" (73). У овом кратком стиху направљена је синтеза његовог живота; али, та синтеза и оцена почива на гласинама („кажу”), док све оно што је централно у збирци долази из перспективе песника. Опозиција која се јавља међу гласовима даје овој песми нешто од метапоетског значења, због чега би се читава песма могла сматрати медитацијом на тему положаја уметника ${ }^{13}$ у друштву и свету, његове судбине и метафизике његовог позива. У том смислу, било би интересантно компаративно сагледати Звездознанчеву смрт са Његошевом песмом Филозоф, астроном и поета.

Идућа песма, Небески прстен, осим што представља артикулацију прстенасте структуре, директно претачући појам Споредног неба у веренички симбол, представља и ону тачку у којој се Попа дотиче најстарије

\footnotetext{
${ }^{13}$ Постоје и таква тумачења која у фигури звездознанца виде фигуру песника: „У књизи Споредно небо налазимо лик Звездознанца; као коментатор свега што се у књизи збива, он представља персону самог песника. Његов је усуд да за собом остави речи 'лепше него свет' и 'теже него кости живота'. Није ли у том усуду Звездознанца садржана и назнака читавог једног песничког програма?” (Лалић 1997: 55); иако се тако нешто не може до краја тврдити на основу самог текста, одређене аналогије између два животна позива се могу успоставити и слутити.
} 
линије песништва, са песмама које „говоре о свадбама небеских тела” (Павловић 1990: VIII). У том смислу, ситуација небеског венчања и свадбе свакако спада у искуство које Попа овом песмом разумева: „Заборавили су и тебе / И своју свадбену ноћ” (74). Антропоморфна карактеризација космоса овде иде у прилог тези да је песничка визија васељене органска, а не механицистичка; остатак Споредног неба, који је доживео метаморфозу, крах и деконструкцију, сада фигурира у виду заручничког прстена. Коначно, његово место у космосу је одређено: „Ево ти домали прст / Скраси се на њему" (74), чиме се прави финална сугестија о човеколикој форми свемира.

Остатак циклуса говори о растакању, кретању и лутању појединих небеских појава, односно о карактеру новог неба које настаје нестанком старог (Ништарија, Сирота одсутност, Мајстор сенки, Звездани пуж). У њима се као доминанта јавља резигнираност која након сведочења судбине Споредног неба наступа, а која се оваплоћује кроз осећаје ништавности, избеглиштва у бесконачности, те крајње узалудности.

Последња песма у циклусу и збирци носи симптоматичан наслов - Звезде избеглице. У тој песми, песнички глас је најогољенији и најгласнији; наиме, након раскола Споредног неба, звезде су освануле „хладне / Далеко од огњишта / Далеко од капије неба" (79). Решење које нуди песник (не можемо веровати да је глас у овој песми астрономов, будући да она у структури долази након Звездознанчеве смрти и да звучи као синтеза и закључак искуства и лирске интерпретације његових речи) састоји се у тајном договору који жели да направи са звездама. Мистичност овог договора почива на чињеници да он треба бити начињен „Кришом да земља не види" (79), јер управо земља (и оно на земљи) не може разумети звездознанчево бављење и она га осуђује на смрт. Песник је тај који, надојен знањем и искуством Споредног неба, може показати пут звездама, дати им путоказе: „Даћу вам вишњев штап / / И путању једну моју бору / И водиљу једну трепавицу / Кући да вас врате” (79).

*

Напослетку, видели смо како се специфична структура од седам циклуса са по седам песама манифестује као оригинална песничка визија космоса, готово као спев о космосу, како га Петров дефинише. Саткан од четрдесет девет песама ${ }^{14}$, поетски комплекс Споредног неба

${ }^{14}$ Интересантно, „Тај број, квадрат од броја 7, има једнако цикличко значење за ламаисте као број четрдесет за Јевреје, хришћане и муслимане. Толико времена је потребно души умр- 
казује целовиту причу од момента ткања и настанка космоса, до његовог растакања; у целини образован на звездознанчевој оставиитини, он је истовремено и апотеоза космичке и метафизичке поетске инспирације, али и метафора могућности стварања света путем уметности, путем лирског израза. Бескрајне су могућности интерпретације и аналогија песничког и астрономског позива које Споредно небо отвара, али је то само један од могућих смерова тумачења ове збирке.

Онај важнији, универзалнији, звонкији и апстрактнији смер, који се тиче саме визије космоса, једног његовог дела и елемената који га творе, покушали смо да у овом раду осенчимо. Тај смер открива визију органског космоса, који се наспрам оног механицистички устројеног успоставља као биће, као жива ствар, као сам човек. Стога, он је прилагодљив, његове промене су могуће, као и грешке (Страно сунце). У његовом грађењу, препознаје се и педантност на језичком плану која одише елиптичношћу. Начин на које песник именује и описује космос утемељен је на традицији народног, говорног, фолклорног језика ${ }^{15}$, али и на појединим сасвим особеним решењима. ${ }^{16}$ Универзум који се тим језиком у овој песничкој творевини обзнањује је „радикално десакрализовани космос” (Лалић 1997: 53), има своје границе, а једна његова галаксија, како напослетку и доживљавамо Споредно небо, само је елемент који твори ширу слику ${ }^{17}$. Тиме не оспоравамо да је то самосвојни, аутентични, до сада невиђени и поетски успелим сликама изграђени део космоса, већ назначавамо да Споредно небо није исто што и читав свемир - који је овде представљен

лог да стигне до свога коначног боравишта, да доврши путовање" (Шевалије, Гербран 2013: 126); ово значење додатно открива дубину Споредног неба, које се онда може посматрати и као лутање звездознанчеве душе након смрти.

${ }^{15}$ Под овим појмом имамо у виду језик који „не подудара се са данашњим. Он [Попа], наиме, враћа језику ону другачију улогу коју је имао у старијим слојевима културе” (Петковић 2004: 226).

${ }^{16}$ Попа за грађење Споредног неба употребљава следећи језички материјал: 1) за шире одређење космоса и његових простора и појава: неповрат плави, неко небо, (ћорави) угао неба, плавет, ведро небо, небеско тле, Млечни пут, празан простор, небеска пучина, модра утроба неба, два зрака, зреник, леви пазух неба, десни пазух неба, небеска ледина, згариште неба, капија неба, небеске двери, муња, гром; 2) за појединачне елементе космоса (звезде, планете, сателите и сл.): звезде падалице, мртве звезде, звездана прашина, звездана киша, поворке звезда, звезде избеглице, звездана раскрсница, небеске покваренице, сунце, сунчево коло, сунчев округли сто, сунчеви зраци, сунчев отац, син сунчевић, слепо сунце, младо сунце, модро сунце, завичајно сунце, црно сунце, старо сунце, млад месец, сазвежђа, свет, мутава земља, земља.

${ }^{17}$ Петров, супротно оваквом мишљењу, сматра да су у питању „Два лексичка тока” која „одговарају основним плановима Споредног неба: плану небеског (главно небо) и плану земаљског (споредно небо), односно духовног и материјалног, узвишеног и профаног” (Петров 1983: 217). 
и означен као нешто што ипак има почетак и крај: улаз, једну и другу падину, један и други пазух неба, те излаз.

Такав космос, уверени смо, представља јединствену појаву у нашој дуготрајној традицији певања о небеским појавама и телима, а Споредно небо у том смислу врло успелу метонимију која прикрива и открива одговоре на космолошка и есхатолошка питања, на питања о смислу егзистенције, положају песника (уметника) у свету; напослетку, оно је још један доказ моћи песничке имагинације и њених градитељских способности.

\section{ЛИТЕРАТУРА}

Попа 1962: В. Попа, Поноћно сунце: зборник песничких сновиђења, Београд: Нолит.

Попа 1973: В. Попа, Споредно небо, Београд: Вук Караџић.

$*$

Лалић 1997: Иван В. Лалић, Проширена белешка о једном трагању за поетиком Васка Попе, у: Н. Петковић (ур.), Поезија Васка Попе: зборник радова, Београд: Институт за књижевност и уметност, Друштво Вршац лепа варош, 49-57.

Лотман 1970: Ј. Лотман, Предавања из структуралне поетике, Сарајево: Завод за издавање уџбеника.

Павловић 1990: М. Павловић, Антологија српског песништва, Београд: Српска књижевна задруга.

Петковић 2004: Н. Петковић, Огледи о српским песницима, Београд: Друштво за српски језик и књижевност Србије.

Петров 1983: А. Петров, Крила и ваздух, Београд: Народна књига.

Попин 2015: А. Попин, Вучје сунще: о поетищи Васка Попе, Нови Сад: Академска књига.

Радовић 2017: Б. Радовић, Записи о Васку Попи, Београд: Службени гласник.

Радуловић 2011: Н. Радуловић, Алхемија у поезији Васка Попе, у: Научни састанак слависта у Вукове дане 40/2, Београд: Међународни славистички центар, 531-539.

Шеатовић Димитијевић 2012: С. Шеатовић Димитријевић, Део као иелина \& иелина као део, Београд: Институт за књижевност и уметност.

Шевалије, Гербран 2013: Ж. Шевалије, А. Гербран, Речник симбола (митови, снови, обичаји, поступщи, облици, ликови, боје, бројеви), Нови Сад: Stylos art, Kiša. 
Uroš M. Ristanović

\section{THE STRUCTURE OF VASKO POPA'S BOOK OF POEMS SECONDARY SKY}

\section{Summary}

Secondary Sky is Vasko Popa's third book of poems, in which the poet presents his authentic lyric vision of the Cosmos. This book shows the stages of the Cosmos, from creation to its metamorphosis and deconstruction. This paper analyzes Secondary Sky from structuralistic standpoint, but it also tends to mark specific position of this book of poem in the context of the Serbian tradition of cosmic poetry.

Key words: Vasko Popa, Secondary Sky, Structuralism, Cosmos, Cosmogony, Cosmism, Astronomy. 